\title{
Conceptual Reference Model for Virtual Factory: Potentials for Collaborative Business
}

\author{
Ahm Shamsuzzoha ${ }^{1}$, Ana Barros ${ }^{2}$, David Costa ${ }^{2}$, Américo Azevedo $^{2,3}$, and Petri Helo ${ }^{1}$ \\ ${ }^{1}$ Department of Production, University of Vaasa, P.O. BOX 700, FI-65101, Finland \\ \{ahm.shamsuzzoha, petri.helo\} @uwasa.fi \\ ${ }^{2}$ INESC TEC, Campus da FEUP, Rua Dr. Roberto Frias, 4200-465, Porto, Portugal \\ \{acbarros,ala\}@inesctec.pt, davidcosta7@gmail.com \\ ${ }^{3}$ FEUP - Faculty of Engineering, University of Porto, \\ Rua Dr. Roberto Frias, 4200-465 Porto, Portugal
}

\begin{abstract}
The concept of combining the power of several independent factories to achieve complex manufacturing processes as so-called virtual manufacturing enterprises is not new and has been addressed by several research projects in recent years. However, there is still a need for adequate methodological support and tools for modelling, structuring and controlling of the next generation of manufacturing systems, such as the virtual factory. In this research, a conceptual virtual factory reference model is presented with the goal to provide companies with general guidelines to manage and monitor the business processes that are needed to create, execute, and dissolve a virtual factory. The virtual factory reference model was built taking into account industrial's requirements and by reviewing the literature in several relevant fields of research such as collaborative networks, supply networks, manufacturing networks, supply chain management, and business processes. Afterwards, it has been validated through its application to future virtual factories of three different industrial sectors: machinery, energy, and semiconductor.
\end{abstract}

Keywords: Virtual factory, collaborative business processes, small and medium enterprises (SMEs), reference model.

\section{Introduction}

The Virtual Factory is a temporary strategic alliance of factories from multiple companies that work together towards developing and bringing to the market innovative products [1]. Its coordinator, the Virtual Factory Broker, has to align processes among partners and ensure that every partner is working towards the same strategic objectives [3]. Although various forms of business networks exist among the manufacturing community nowadays, methodologies to form and execute such virtual networks are still scarce. A need for strong methodological support and processes for modelling, structuring and control of the virtual manufacturing system is recognized. The present paper addresses this research gap by offering the necessary guideline for companies to start up their virtual factory collaboration. 
The conceptual virtual factory reference model proposed in this research is a process framework to structure how work is accomplished and monitored among partners and is therefore a very useful tool for the individual enterprises to set up and operate a virtual factory of a dynamic and inter-enterprise network for complex product manufacturing. The presented model highlights a framework for collaborative design and operations of network manufacturing systems. It consists of business processes for virtual factories and is organized in the four phases needed to run a virtual factory - Join, Plug, Play and Dissolve. This model is used to formulate the business processes harmoniously with each other. The fact is that it supports distributed value chain mapping among collaborative companies.

\section{Virtual Factory: A Way Out for Collaborative Business}

Several frameworks for Virtual collaborations among SMEs were developed in order to address network collaboration and to support companies, mostly SMEs in the successful formation and operation of Virtual Factories. In 2007, Camarinha-Matos and Afsarmanesh developed the ARCON (A Reference model for Collaborative Networks) modeling framework to provide a model that can be instantiated to capture the definitions of all potential Collaborative Networked Organizations (CNOs) [2]. This framework also supports the co-working and co-development among the stakeholders and provides the high level base for design and building of the architectural specifications of modular CNO components. In 2009, Romero and Molina developed an Integral Business Process Management (I-BPM) framework with the view to explain a set of process models that depict what happens during each VBE (Virtual Organization Breeding Environment) and VO management processes [3].

Romero and Molina [7] presented a model-based VBE reference model that focuses on providing a comprehensive overview of the key elements/components of a breeding environment and the main requirements to create and manage $\mathrm{VO}$ during its entire lifecycle. Shamsuzzoha et al. [8] (2010) provided an implementation framework for business collaboration within a non-hierarchical business network that supports the logical approaches of the formation and operation of a business network. In 2010, Boukadi et al. [9] proposed a framework for meeting the flexibility and agility of requirements for collaborative business using a multi-layer approach. Chituc et al. [10] proposed a conceptual framework towards seamless interoperability in a collaborative networked environment following a service-oriented approach.

This literature shows that several conceptual frameworks have been already developed to support collaborative networked organizations; however these lack on completeness and fail to provide empirical evidence for their functioning. In this research, we were able to create a comprehensive reference model taking into account industrial's requirements and by reviewing various streams of literature: collaborative networks, supply networks, manufacturing networks, supply chain management, and business processes. Furthermore, empirical validation was gathered for this holistic approach in three different industrial sectors namely, machinery, energy and semi-conductor. 


\section{$3 \quad$ Research Methodology}

In order to identify a comprehensive list of business processes needed for the creation, execution and dissolution of virtual factories, several fields of research were considered: collaborative networks, supply networks, manufacturing networks; supply chain management, and business processes. Table 1 summarizes the results of the literature review and provides an overview of the high-level processes of the virtual factory reference model.

The reference model was validated and refined by means of hands-on workshops with managers, who used the virtual factory reference model as the supporting management tool for the design of their future virtual factories. The workshops were the simulation of a kick-off meeting for the virtual factory creation and were based on a real situation and need currently experienced by the companies. The workshops contributed to refine the reference model. Table 2 summarizes some characteristics of these virtual factories.

Table 1. Virtual factory business processes (CN: Collaborative Networks; SN: Supply Networks; MN: Manufacturing Networks; SCM: Supply Chain Management; BP: Business Processes)

\begin{tabular}{|c|c|c|c|c|c|c|c|c|c|c|}
\hline \multirow[b]{2}{*}{ Process } & \multicolumn{3}{|c|}{$\mathrm{CN}$} & \multirow{2}{*}{$\begin{array}{l}\text { SN } \\
\Xi \\
\Xi\end{array}$} & \multirow{2}{*}{$\begin{array}{l}\mathrm{MN} \\
\sqrt{\Xi}\end{array}$} & \multicolumn{3}{|c|}{ SCM } & \multicolumn{2}{|c|}{$\mathrm{BP}$} \\
\hline & $\bar{\beth}$ & $\begin{array}{l}\exists \\
\dot{v}\end{array}$ & $\begin{array}{l}\bar{m} \\
\stackrel{1}{\Xi}\end{array}$ & & & $\stackrel{\sigma}{=}$ & 正 & $\sqrt{6}$ & こ & $\sqrt{\Omega}$ \\
\hline \multicolumn{11}{|l|}{ Join } \\
\hline To understand Business Opportunities & $\mathrm{X}$ & $\mathrm{X}$ & $\mathrm{X}$ & & & & & & & \\
\hline Set-up the virtual factory (ICT) framework & $\mathrm{X}$ & $\mathrm{X}$ & $\mathrm{X}$ & $\mathrm{X}$ & & & & $\mathrm{X}$ & & $\mathrm{X}$ \\
\hline Analyse market trends & $\mathrm{X}$ & $\mathrm{X}$ & $\mathrm{X}$ & & & & & & & \\
\hline Select and invite partners to join the network & $\mathrm{X}$ & $\mathrm{X}$ & $\mathrm{X}$ & & & & & & & \\
\hline $\begin{array}{l}\text { Collect information about partners' products, } \\
\text { services, competencies and capacities }\end{array}$ & $\mathrm{X}$ & $\mathrm{X}$ & $\mathrm{X}$ & & $\mathrm{X}$ & & & & & \\
\hline \multicolumn{11}{|l|}{ Plug } \\
\hline Search and assign partners in the network & $\mathrm{X}$ & $\mathrm{X}$ & $\mathrm{X}$ & $\mathrm{X}$ & & & & & & \\
\hline Define contractual and NDA conditions & $\mathrm{X}$ & $\mathrm{X}$ & $\mathrm{X}$ & & $\mathrm{X}$ & $\mathrm{X}$ & & & & \\
\hline Define the virtual factory business model & $\mathrm{X}$ & $\mathrm{X}$ & $\mathrm{X}$ & & $\mathrm{X}$ & & & $\mathrm{X}$ & & $\mathrm{X}$ \\
\hline Define network's governance model & $\mathrm{X}$ & $\mathrm{X}$ & $\mathrm{X}$ & & $\mathrm{X}$ & $\mathrm{X}$ & $\mathrm{X}$ & $\mathrm{X}$ & $\mathrm{X}$ & $\mathrm{X}$ \\
\hline Make operational plan and processes & $\mathrm{X}$ & $\mathrm{X}$ & $\mathrm{X}$ & & $\mathrm{X}$ & $\mathrm{X}$ & & & & \\
\hline Manage risks & $\mathrm{X}$ & $\mathrm{X}$ & $\mathrm{X}$ & $\mathrm{X}$ & & & $\mathrm{X}$ & & & $\mathrm{X}$ \\
\hline
\end{tabular}


Table 1. (Continued)

\begin{tabular}{|c|c|c|c|c|c|c|c|c|c|c|}
\hline \multirow[b]{2}{*}{ Process } & \multicolumn{3}{|c|}{$\mathrm{CN}$} & \multirow{2}{*}{$\begin{array}{l}\text { SN } \\
\Xi \\
\Xi\end{array}$} & \multirow{2}{*}{$\begin{array}{l}\mathrm{MN} \\
\sqrt{\Xi}\end{array}$} & \multicolumn{3}{|c|}{ SCM } & \multicolumn{2}{|c|}{ BP } \\
\hline & $\widetilde{\beth}$ & $\begin{array}{l}\Xi \\
\dot{\theta}\end{array}$ & $\begin{array}{l}\bar{m} \\
\stackrel{\Xi}{\Xi}\end{array}$ & & & $\stackrel{\sigma}{=}$ & $\Xi$ & $\sqrt{6}$ & $\Xi$ & $\sqrt[\Omega]{\Omega}$ \\
\hline \multicolumn{11}{|l|}{ Play } \\
\hline Design and develop expected product & & & $\mathrm{X}$ & & & $X$ & & & $X$ & $\mathrm{X}$ \\
\hline Manufacture product & & & $\mathrm{X}$ & & & $\mathrm{X}$ & $\mathrm{X}$ & $\mathrm{X}$ & $\mathrm{X}$ & $\mathrm{X}$ \\
\hline Fulfill customer order & $\mathrm{X}$ & $\mathrm{X}$ & $\mathrm{X}$ & & $\mathrm{X}$ & $\mathrm{X}$ & $\mathrm{X}$ & $\mathrm{X}$ & $\mathrm{X}$ & $\bar{X}$ \\
\hline $\begin{array}{l}\text { Define process plan and schedule operational } \\
\text { activities }\end{array}$ & $\mathrm{X}$ & $\mathrm{X}$ & $\mathrm{X}$ & & & & & & & \\
\hline $\begin{array}{l}\text { Monitor operational processes on real-time } \\
\text { environment }\end{array}$ & $\mathrm{X}$ & $\mathrm{X}$ & $\mathrm{X}$ & $\mathrm{X}$ & $\mathrm{X}$ & $\mathrm{X}$ & $\mathrm{X}$ & $\mathrm{X}$ & $\mathrm{X}$ & \\
\hline Adapt processes according to the needs & $\mathrm{X}$ & $\mathrm{X}$ & $\mathrm{X}$ & $\mathrm{X}$ & $\mathrm{X}$ & $\mathrm{X}$ & $\mathrm{X}$ & $\mathrm{X}$ & $\mathrm{X}$ & \\
\hline \multicolumn{11}{|l|}{ Dissolve } \\
\hline Evaluate virtual factory partners & $\mathrm{X}$ & $\mathrm{X}$ & $\mathrm{X}$ & & & & & & & \\
\hline Share benefits among partners & $\mathrm{X}$ & & $\mathrm{X}$ & $\mathrm{X}$ & & $\mathrm{X}$ & & & & $\mathrm{X}$ \\
\hline Assign liabilities among partners & $\mathrm{X}$ & & $\mathrm{X}$ & & & & & & & \\
\hline Virtual factory performance feedback & $\mathrm{X}$ & $\mathrm{X}$ & $\mathrm{X}$ & & & & & & & \\
\hline Store the valuable knowledge and expertize & $\mathrm{X}$ & $\mathrm{X}$ & $\mathrm{X}$ & & & & & & & \\
\hline Maintain intellectual proprietary right & & & & & & & & & & \\
\hline
\end{tabular}

Table 2. Characteristics of the validation cases

\begin{tabular}{|c|c|c|c|}
\hline Case & Industry & Virtual factory goal & Partners' profile \\
\hline $\mathrm{A}$ & Machinery & $\begin{array}{l}\text { Design, build and deliver } \\
\text { a new machine }\end{array}$ & $\begin{array}{l}\text { - Machine Manufacturer } \\
\text { - Producer of mechanical } \\
\text { equipment } \\
\text { - Company specialized in } \\
\text { surface treatment } \\
\text { - Software company }\end{array}$ \\
\hline B & Energy & $\begin{array}{l}\text { Design, build and } \\
\text { promote new technologies } \\
\text { in the energy technology } \\
\text { sector }\end{array}$ & $\begin{array}{l}\text { - } \quad \text { Technology centre } \\
\text { - R\&D provider } \\
\text { - Energy producer and distributor } \\
\text { - Technology provider }\end{array}$ \\
\hline $\mathrm{C}$ & $\begin{array}{l}\text { Semicondu } \\
\text { ctor }\end{array}$ & $\begin{array}{l}\text { Industrialize a new } \\
\text { technology and launch it }\end{array}$ & $\begin{array}{l}\text { - Semiconductor manufacturer } \\
\text { - R\&D Partner } \\
\text { - Key raw material supplier } \\
\text { - Foundry }\end{array}$ \\
\hline
\end{tabular}




\section{Virtual Factory Conceptual Reference Model}

The virtual factory (VF) conceptual reference model is developed as part of work accomplished within the ADVENTURE project under the funding from European Commission (Ref. 285220) [18]. This model basically provides the necessary guidelines to form a plug-and-play virtual factory to be used for achieving the identified business opportunity.

The developed reference model consists of three levels. In the first level it describes the main phases of the VF lifecycle [1], whereas, the second level highlights the business processes for each of these VF life cycle phases. The third level contains the activities of each sub-process.

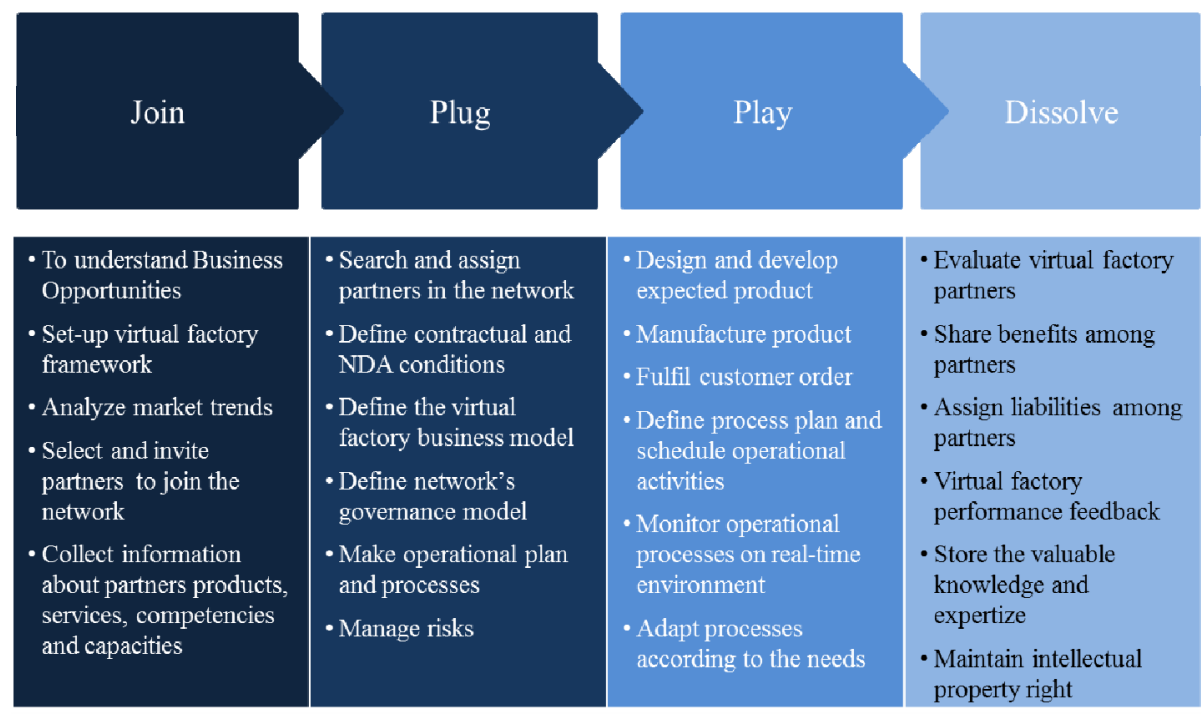

Fig. 1. Virtual factory conceptual reference model

From the reference model as highlighted in Figure 1, it is noticed that in the Join phase participating partners first of all need to join the ICT framework and to understand the identified business opportunities after analyzing the current market trends clearly in order to enthusiastically and actively join the VF network. At this phase, the VF broker also collects the necessary information of the participating partners with respect to their products portfolios, services, competencies and capacities. Potential partners are searched and assigned with specific tasks or processes in the Plug phased of the reference model. Essential contractual agreement within the network partners are defined a non-disclosure agreement (NDA) conditions are signed to protect intellectual property rights. Both the business model [19] and governance model [20] are defined to execute the VF during this phase. Finally, processes and operational planning of the VF network are also done at this plug phase along with the response plan of potential risks. 
During the Play phase of the reference model the VF broker begins necessary steps to design and develop the target product. At this phase, essential design and drawing of the expected product is performed in a collaborative manner among partners [21]. Since the production process can be monitored through the ICT platform, the reference model also considers the monitoring of operational processes on real-time environment with the objective to find abnormality if there is any and to initiate required solution after consulting with the predefined response plan. At this phase, there is an option to adapt any processes in case of need. When the identified business opportunity is over the Dissolve stage of the reference model is evoked. At this phase, overall performances of the VF partners are evaluated based on agreed criterions. The expected benefits and liabilities are shared between the partners along with maintaining intellectual property rights. The expert knowledge and valuable information are stored for future use before dissolving the virtual factory.

Each of the main processes and its accompanied sub-processes can be defined in detail using BPMN (Business Process Model and Notation) diagram as has been proposed for example by Romero and Molina [3]. In our research we took a more operations management perspective and used the input-transformation-output model to describe each process [22]. Figure 2 highlights a sample input-transformationoutput model of a process named as 'Define Virtual Factory Business Model'.

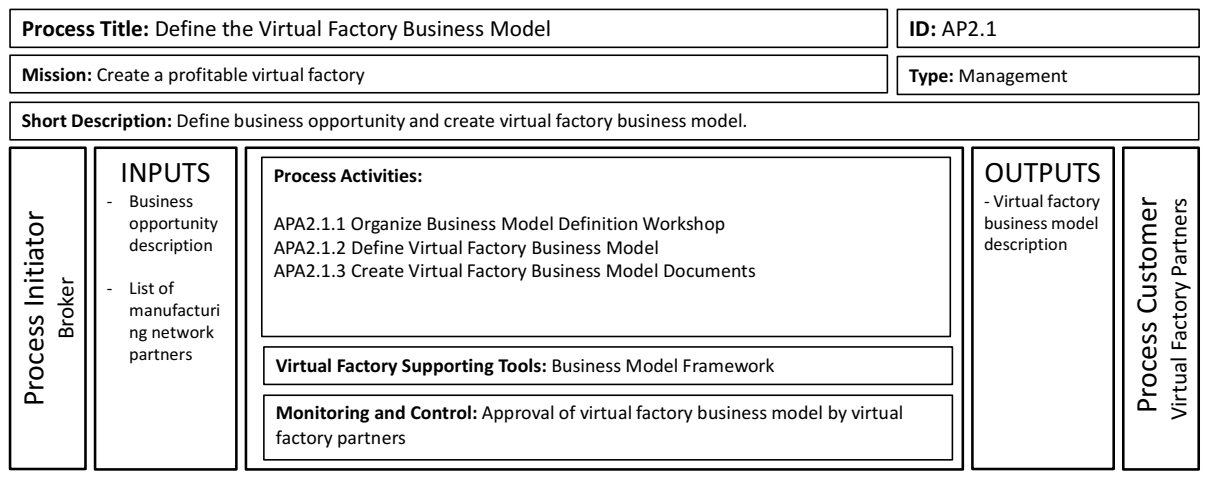

Fig. 2. Sample Input-Transformation-Output model for 'Define the Virtual Factory Business Model'

\section{$5 \quad$ Discussion and Conclusions}

The virtual factory reference model is a management tool used to design and manage a temporary strategic alliance among companies formed to exploit a new business opportunity. From the validation workshops we conclude that it is useful for managers operating a virtual factory because it:

- provides a structured guideline to help with the implementation of a virtual factory, so that managers to not have to start from scratch, 
- provides a comprehensive list of processes giving managers an overview of the implementation scope, i.e., of what has to be done to implement a virtual factory,

- provides generic definitions of concepts that assist partners to create a common understanding among them,

The presented conceptual reference model is tested within three business networks, where it approves most the associated business processes and practices. Some processes and practices are not presented within these case networks but can be applicable in other networks too. In future research, this framework will be tested and validated within several virtual networks working in various business domains with the objective to offer a generic framework to be used in future virtual factory business networks.

Acknowledgements. The research leading to these results has received funding from the European Union Seventh Framework Programme (FP7/2007-2013) under grant agreement $\mathrm{n}^{\circ}$ FoF-ICT-2011.7.3 - 285220 (Adventure Project - ADaptive Virtual ENterprise ManufacTURing Environment). INESC TEC team research was also supported by the Project "NORTE-07-0124-FEDER-000057", financed by the North Portugal Regional Operational Programme (ON.2 - O Novo Norte), under the National Strategic Reference Framework (NSRF), through the European Regional Development Fund (ERDF), and by national funds, through the Portuguese funding agency, Fundação para a Ciência e a Tecnologia (FCT).

\section{References}

1. Camarinha-Matos, L.M., Afsarmanesh, H., Galeano, N., Molina, A.: Collaborative Networked Organizations - Concepts and Practice in Manufacturing Enterprises. Computers \& Industrial Engineering 57(1), 46-60 (2009)

2. Camarinha-Matos, L.M., Afsarmanesh, H.: A Comprehensive Modeling Framework for Collaborative Networked Organizations. Journal of Intelligent Manufacturing 18(5), 529542 (2007)

3. Romero, D., Molina, A.: VO Breeding Environments \& Virtual Organizations Integral Business Process Management Framework. Information Systems Frontiers 11(5), 569-597 (2009)

4. Supply-Chain Council (SSC) SCOR®: Supply-Chain Operations Reference Model. Version 9.0 (April 2008), http: / / www. supply-chain.org

5. American Productivity and Quality Center (APQC): APQC's Process Classification Framework $^{\mathrm{SM}}$. Version 6.0.0 (July 2012), http: / / www . apqc . org/

6. Voluntary Interindustry Commerce Standards (VICS): Collaborative Planning, Forecasting and Replenishment (CPFR@) (May 2004), http: / / www. vics . org / docs / committees/cpfr/CPFR_Overview_US-A4.pdf

7. Romero, D., Molina, A.: Virtual Organization Breeding Environments Toolkit: Reference Model, Management Framework and Instantiation Methodology. Production Planning \& Control 21(2), 181-217 (2010) 
8. Shamsuzzoha, A., Kankaanpää, A., Carneiro, L., Helo, P.T.: Implementation Framework for Collaboration in a Non-Hierarchical Business Network. In: IEEE International Conference on Industrial Engineering and Engineering Management (IEEM 2010), Macau, China, December 7-10, pp. 2254-2258 (2010)

9. Boukadi, K., Vincent, L., Ghedira, C.: A Multi-Layer Framework for Virtual Organizations Creation In Breeding Environment. In: Camarinha-Matos, L.M., Boucher, X., Afsarmanesh, H. (eds.) PRO-VE 2010. IFIP AICT, vol. 336, pp. 287-296. Springer, Heidelberg (2010)

10. Chituc, C.M., Azevedo, A., Toscano, C.: A Framework Proposal for Seamless Interoperability in a Collaborative Networked Environment. Computers in Industry 60(5), 317-338 (2009)

11. Hormazábal, N., de la Rosa, J.L.: On the Management of Virtual Organizations Dissolution (In Virtual Business Networks). In: Camarinha-Matos, L.M., Pereira-Klen, A., Afsarmanesh, H. (eds.) PRO-VE 2011. IFIP AICT, vol. 362, pp. 167-174. Springer, Heidelberg (2011)

12. Shamsuzzoha, A., Kankaanpaa, T., Carneiro, L.M., Almeida, R., Chiodi, A., Fornasiero, R.: Dynamic and Collaborative Business Networks in the Fashion Industry. International Journal of Computer Integrated Manufacturing 26(1-2), 125-139 (2013)

13. Ferreira, P.S., Cunha, P., Shamsuzzoha, A., Toscano, C.: Framework for Performance Measurement and Management in a Collaborative Business Environment. International Journal of Productivity and Performance Management 61(6), 672-690 (2012)

14. Harland, C., Zheng, J., Johnsen, T., Lamming, R.: A Conceptual Model for Researching the Creation and Operation of Supply Networks. British Journal of Management 15(1), 1$21(2004)$

15. Montreuil, B., Frayret, J.-M., D’Amours, S.: A Strategic Framework for Networked Manufacturing. Computers in Industry 42(2-3), 299-317 (2000)

16. Croxton, K.L., Garcia-Dastugue, S.J., Lambert, D.M., Rogers, D.S.: The Supply Chain Management Processes. The International Journal of Logistics Management 12(2), 13-36 (2001)

17. Garvin, D.: The Processes of Organization and Management. Sloan Management Review 39(4), 33-50 (1997)

18. ADVENTURE (Adaptive Virtual Enterprise Manufacturing Environment), European RTD project, Grant agreement no: 285220, Duration September 01, 2011-August 31, 2014 (2011)

19. Rojas, E.P.S., Barros, A.C., de Azevedo, A.L., Batocchio, A.: Business Model Development for Virtual Enterprises. In: Camarinha-Matos, L.M., Xu, L., Afsarmanesh, H. (eds.) PRO-VE 2012. IFIP AICT, vol. 380, pp. 624-634. Springer, Heidelberg (2012)

20. Provan, K.G., Kenis, P.: Modes of Network Governance: Structure, Management, and Effectiveness. Journal of Public Administration Research and Theory 18(2), 229-252 (2008)

21. Cadden, T., Downes, S.J.: Developing a Business Process for Product Development. Business Process Management Journal 19(4), 715-736 (2013)

22. Slack, N., Chambers, S., Johnston, R., Betts, A.: Operations and Process Management: Principles and Practice for Strategic Impact. Prentice Hall (2006) 